Int. J. Dev. Biol. 50: 333-340 (2006)

doi: $10.1387 / \mathrm{ijdb} .052053 \mathrm{nt}$

\title{
The role and limits of a gradient based explanation of morphogenesis: a theoretical consideration
}

\author{
NIKOLOZ TSIKOLIA* \\ Institut für Biochemie, Medizinische Fakultät, Universität Leipzig, Germany
}

\begin{abstract}
Development of an organism is a multi-dimensional process leading to the generation of complex species-specific structures. This specificity suggests machine-like organisation. The uneven distribution (gradient) of soluble substances (morphogens) and specific receptorligand interactions are known to cause differential gene expression. Therefore gradients of morphogens are used as a causal explanation of developmental processes. However each attempt to describe development causally should take into account both the local fine organisation and global robustness of morphogenesis. The classical view of the role of morphogens will be critically considered and possible alternative proposed. The core idea of $\mathrm{my}$ proposal is that the main function of morphogenetic substances could be a context dependent modification of cell behaviour. Both history and different features of morphogenetic fields create the framework for the activity of morphogenes.
\end{abstract}

KEY WORDS: embryonic development, gradient, morphogenesis, epigenetic factor, developmental pathway

\section{Causality and explanation: the role of boundary condi- tions}

The issue of the causal factors in morphogenesis and development is both fascinating and fuzzy. In order to clarify some important concepts of developmental biology it seems appropriate to make some general statements about explanation and causation. In philosophy the metaphysics of causation is subject of never ending discussion. At the same time the natural sciences, especially biology, use this concept in an oversimplified manner. In my opinion the high complexity of biological questions and the enormous knowledge accumulated in the last few decades calls upon natural scientists to be more careful with our explanations. At the same time I believe that philosophical discussions will benefit from the clarification made feasible by increasing interdisciplinary discussion. Natural science has come of age and is increasingly able to use complex causal explanation. In order to understand developmental processes we need insight into mathematics, as Gilbert and Sarkar (2000) have recently argued: the "combination of microarray and computer technology may finally allow us to have a multivariable developmental biology of the kind that Bertalanffy and Weiss would have appreciated". This however makes it necessary to re-evaluate our theoretical approaches to biology in general and to development in particular. Hence theoretical and philosophical suggestions cannot be ignored. The explanation of any event in nature requires a description of its context or (boundary) conditions. I define here boundary conditions as the necessary conditions of the phenomena under investigation. We can observe physical laws and forces only within certain contexts. This is very trivial: we cannot observe free fall of the stone so long we hold it. Every state could be described as a configuration (pattern) of different physical forces, every change of the state as change in this pattern. Aristotle in his theory about causality already used (boundary) conditions as explanatory significant factors. He introduces four different forms of an explanation or a cause $(\alpha \iota \tau \iota \alpha)$ (see e.g. Barnes, 1982). One of them, causa formalis, is especially important for our purposes; this can be described as the pattern or nature (what is?) of the phenomenon. Other causes are material or substratum, purpose or good and source of the change (Metaphysics B:I, P:3). In posterior analytics (A. Post, B:II, P:2) Aristotle asks "What is a [lunar] eclipse" and gives the answer "The privation of the moon's light by interposition of the earth". Thus the pattern of the circumstances including moon, earth and light is used as explanation of an eclipse. Since for Aristotle the question "What is.?" is identical with "What is the reason of.?", the pattern could be considered as

Abbreviations used in this paper: AP, anterior-posterior; bcd, bicoid; BMP, bone morphogenetic protein; DPP, Drosophila Decapentaplegic protein; FGF, fibroblast growth factor; RA, retinoic acid; Shh, sonic hedgehog; SVZ, subventricular zone; TGF, transforming growth factor; ZPA, zone of polarising activity.

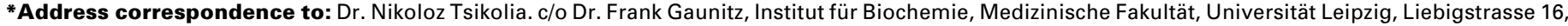
04103 Leipzig, Germany. Fax: +49-341-97-22-109. e-mail: nikoloztsikolia@hotmail.com
} 
causal factor (A. Post, B:II, P:2). It is clear that boundary conditions or context are a necessary component for each physical event to be explained. But one tends to deny their causal role by claiming that only an efficient cause (the source of the change) is of explanatory relevance (Mahner and Bunge, 1997). On the other hand it was emphasised that for real physical complex systems (e.g. the Bénard convection) boundary conditions play crucial causal role (Anderson and Stein, 1987). As Michael Polanyi (1969) argued, the same is true for machines. In his view a machine cannot be explained in terms of physics and chemistry: principle of structure controls the principles of physics and chemistry.

It could be suggested that the notion of the causa formalis is of great importance to biology, since it explains how a certain change can occur even in the absence of an efficient cause. Such situations are common in biology: if some function could not be performed, or if some substance is not available, the organism can nevertheless undergo a change. In such cases the boundary conditions play an undoubtedly causal role. This causal role performed by boundary conditions is especially important for the explanation of development. This is because development is a process that not only uses previously existing conditions, but also creates new conditions. Recently the idea has become increasingly widespread that the role of the causa formalisin the origin of morphological novelties is crucial and has increasingly grown over the course of biological evolution (Newman and Müller, 2001).

Unfortunately the consideration of the notion of a context is outside the scope of most recent approaches to morphogenesis. Instead, the efficient molecular factors - morphogens and morphogen-mediated interactions are regarded as crucial explanatory tools in developmental biology. This concept implies that uneven distribution of morphogens (usually in the form of a gradient) leads to a stepwise symmetry breaking in embryo and to its subsequent morphogenesis and differentiation.

\section{History of the gradient concept}

The idea of gradients in developing organisms is very old. Theodor Boveri (Boveri, 1901) seems to be the first who suggested that a gradient (Gefä/), or differential concentrations of substances, determines the cell's fate. Later Child developed a detailed theory of gradients (Child, 1941). His idea was based on experimental results showing different regenerative potencies in planarians and other lower invertebrates along the anterior-posterior axis. The gradient postulated by Child was a metabolic one and assumed to be generated by unspecific external excitation and its transmission. Therefore the formation of the gradient was possible without any pre-existing differentiation (op cit., pp. 702). Child also recognized the relation between gradients and genes: "If a gradient extends over more than a single cell, cell along its course represent different levels and these differences provide a basis in difference of gene action, certainly an essential factor in differentiation" (op cit., pp. 298).

The famous experiments of Sven Hörstadius (1939) demonstrated differences in the developmental potencies along the animal-vegetal axis in sea urchin embryo. It was shown that the limitation of the fate of embryonic substratum is related to its position within embryo in a gradual manner. Hörstadius interpreted his results in terms of gradients of animalizing and vegetalizing substances. The gradient view is closely related to the concept of positional information (see e.g. Wolpert 1996). This concept implies that the cells acquire a positional value with respect to boundaries and then interpret it in terms of a programme determined by their genetic constitution and developmental history. The concept of morphogen was introduced a class of substances causing a specific outcome of development. The positional value was assumed to be generated by interaction of a cell with different concentrations of a morphogen. Morphogens are defined as soluble substances that diffuse from the site of their synthesis and thus form a concentration gradient. The first clear demonstration of morphogen gradient and its role in the development of Drosophila melanogasterwas provided by Driever and Nüsslein-Vollhard (1988). During the last two decades the knowledge about morphogens has been expanded enormously. Different questions may arise with regard to gradient-based theory. Why do we need gradientbased explanation? Where do the gradients originate? What is their proximate effect? And what is their real role in morphogenesis?

\section{The logical and natural necessity of morphogens in gradient formation}

The existence of different types of cells within an organism and its precise morphology requires causal explanation. Specific physical interactions should be responsible for the successive breaking of symmetry within an organism and for the specification of its parts. The following theoretical reasons imply the logical necessity of a morphogen-based theory:

(i) Since the genomes are equivalent in all cells, the cause of heterogeneity should be extrinsic (epigenetic): signals from the outside should be responsible for varying gene expression.

(ii) It is known that specific receptor-ligand interactions are able to modify gene expression.

(iii) Ligands are external signals.

(iv) Thus these molecular ligands should be unevenly distributed in order to activate genes in different ways.

How will this distribution be generated? The theory of the diffusible morphogen which forms a gradient has seen more success in recent years (Lawrence 2001, Ephrussi and St. Johnston, 2004). Mechanisms of diffusion have been subject to intensive study (Belenkaya et al., 2004, Smith and Gurdon, 2004). Different experiments showed the concentration-dependent action of morphogens. For example, activin (a substance from TGF-beta group) is able to act in a concentration-dependent manner (Gurdon and Bourillot, 2001). Activin-loaded beads were placed in a spherical cell reaggregate of two face-to-face animal caps of a Xenopus blastula. Experiments showed that higher activin concentrations lead to the expression of organizer- specific goosecoid and lower concentrations to the expression of mesodermal marker Xbrachyury. Not only was gene expression achieved, but so was specific cell differentiation. Asashima and his co-workers (2000) induced different types of tissues by applying different concentrations of activin.

How is this distribution generated? Self-organisation and simple or regulated diffusion come into the question. The theory 
of the diffusible morphogen which forms a gradient was more successful in recent years.

\section{Problems associated with morphogen based expla- nations}

As stressed above, the explanation of symmetry-breaking exclusively by previously existing local asymmetry is not appropriate. The uneven distribution of morphogens by diffusion already requires established asymmetry. This leads to an infinite explanatory regress. But even if we attempt to explain the breaking of symmetry with reference to a hidden infinite regress, every fluctuation would lead to disorder of the developmental "program". Hence it seems that the main problem of gradient-based explanation is that molecular events are not robust. The discovery of the highly robust character of development contradicts the specific nature of molecular interactions within the cell (Namba et al., 1997, Knecht and Harland, 1997, Hochmandzadeh et al., 2002, Stern et al., 2004, for theoretical consideration and reviews see Goodwin, 1996, Beloussov, 1998, Kirschner et al., 2000, Gilbert and Sarkar, 2000, Jaeger et al., 2004). Normal development can occur despite variability in cell number (Frankhauser, 1945, Day and Lawrence, 2000), size of embryo (Rands, 1986, Power and Tam, 1993, Kirschner et al., 2000) and macroscopic mechanisms (equifinal regulation). Equifinal development leads to formation of very similar structures from similar or even identical initial conditions by different spatial pathways (Wagner, 1994, Cherdantsev, 2003). Cherdantsev and Krauss (1996) demonstrated the remarkable variability of the mechanisms of gastrulation in development of the colonial hydroid, Dynamena pumila.

Development is also robust in regard to alterations of morphogen activity. Bicoid (bcd) is a transcriptional factor crucial for formation of the anteroposterior axis of the Drosophila embryo acting in a concentration-dependent fashion. Change of bcd concentration leads to initial deviation of the developmental program in $D$. melanogaster including changes in gene expression and early morphological markers. However, these alterations regulate so that a normal adult fly is developed (Namba et al., 1997). Therefore the correct pattern can be generated despite changes of both molecular and morphologic processes. It was additionally shown that although gradients of bcd display a high embryo-to-embryo variability, the subsequent reaction of tissue on bcd is highly robust and the noise is filtered out (Houchmandzadeh et al., 2002).

Another crucial suggestion comes from teratology. Both experimental manipulation and observed anomalies support the global role of morphogens: patterns of most abnormalies could be systematized using macroscopic categories and this suggests reaction of embryonic tissue in toto (for review see Tsikolia, 2003). Applications of morphogenetically active substances can result in global reactions within the tissue (second axis formation, organiser or limb duplication, etc.). The mutant phenotypes, in which the proper functioning of certain morphogenetic active substances is blocked, can be rescued by simple external administration of the same substances. Accordingly, the most successful interpretation of human abnormalities occurs in the framework of field theory (Martinez-Frias et al., 1998). On the other hand, as shown by plethora of experiments in last 20 years mentioned above, the molecular events indeed play an important role in pattern formation. One approach to solving this apparent contradiction could be the study of the stabilizing role of boundary conditions. The readout of the gradient was shown to be crucial for the effect of the bicoid gradient on establishment of the hunchback gradient (Hochmandzadeh et al., 2002). The question that arises is what kind of boundary condition is active in the organism and how might it correct the deviations of the gradients?

Additional insights into the complexity of the action of morphogens were provided recently. It was found that a morphogen can be distributed not only by the diffusion of protein from its source, but also through the polarized growth and decay of mRNA (Dubrulle and Pourquie, 2004). The authors have shown that FGF8 mRNA is produced in growing posterior tip tissue and is later degraded, resulting in the formation of an mRNA gradient in the posterior part of the embryo. Another interesting observation provided by Harfe and his team (2004) further challenges the spatial gradient model. The authors studied the mode of action of sonic hedgehog (Shh) in the patterning of vertebrate digits. Sonic hedgehog is a well-studied substance and was considered to be a prototypical diffusible morphogen (Zeng et al., 2001). However, it was shown that the patterning of the limb bud occurs via the migration of the cells previously expressing of Shh, rather than by the cell's sensing their position in Shh gradient (Harfe et al., 2004).

The data presented above suggested that both the real role of morphogen and its distribution throughout the tissue are not compatible with classical concepts. Moreover additional, nonlocal principles were shown to play causal roles in development.

\section{The role of mechanical stresses}

Mechanical stresses were demonstrated to play a crucial role in pattern formation and morphogenesis (Harris, 1987, Beloussov, 1998). It was shown that stretching of Xenopus suprablastopore zone perpendicularly to the AP axis leads to the axis formation which is perpendicular to the prospective head-tail orientation (Beloussov et al., 1988, Beloussov and Ermakov, 2001). Induction of involution movements within ventro-lateral parts of Xenopus early gastrula results in the formation of axial rudiments in abnormal locations (Beloussov and Snetkova, 1994). Similar mechanical manipulations lead to inversion of dorso-ventral polarity in the loach embryo (Cherdantsev, 2003). In the both cases axis formation was induced on the side opposite to the prospective. Artificial alteration of mechanical stresses in the Drosophila embryo leads to change of gene expression profile (Farge, 2003). Uneven distribution (gradients) of morphogens at early stages is the subject of intensive investigation. Dorso-ventral and animalvegetative gradients in Xenopus blastula are believed to be causes of embryonic axis formation (de Robertis et al., 2000). However, different mechanical manipulations cause changes in the fate of embryonic material already supposedly prepatterned by gradients of morphogens. Thus mechanical stresses undoubtedly play causal roles in developmental processes. It could be proposed that the mechanics of embryo could well constitute the causal acting boundary conditions that we require.

At the cellular level the role of mechanics is also being investigated. Cells and their genomes are able to respond upon mechanical influence in a specific manner (Opas, 1994, Ingber, 2003). The role of the mechanics of flow in blood vessels and 
heart formation was suggested a long time ago (Spitzer, 1923). Recently alteration of gene expression in response to flowinduced forces was shown for both cardiac and vascular endothelial cells (Garcia-Cardena et al., 2001, Hove et al., 2003). Flow occlusion during cardiac development leads to the formation of hearts with an abnormal third chamber, diminished looping and impaired valve formation (Hove et al., 2003). The reaction of the cell upon mechanical influence is specific (Carcia-Cardena et al., 2001). Cells are able to distinguish between different mechanical stimuli, for example between uniaxial and multiaxial forces (Hornberger et al., 2005).

\section{Cell behaviour as a target of morphogens?}

Huang and Ingber (2000) suggested that the behaviour of a cell can be described in the framework of an attraction-based model. They describe five different modes of cell behaviour (quiescence, apoptosis, proliferation, differentiation and movement) as stable states. Consequently, these states can be changed or stabilized by different kinds of external influence - both specific molecular and unspecific physical ones - and hence contribute to development or homeostasis. According to these authors the control of cell function involves "selection of preexisting (latent) behavioural modes of the cell, rather than instruction by specific binding molecules" (Huang and Ingber, 2000).

Therefore it is possible that the main role of morphogens is in modifying cell behaviour leading to competence-dependent cell differentiation. In this case the role of a morphogen would be permissive rather than instructive. This idea also provides a possible explanation for embryonic regulation: permission could have different context-dependent codes.

Since morphogens act in the context of global multicellular developmental processes, their role could be to modify these processes. Morphogens could modify the state of a cell by canalizing it into one of pre-existing behavioural modes according to the model proposed by Huang and Ingber (2000). The set of possible behavioural modes of a cell can be called the competence that is classically defined as "ability to respond to a specific inductive signal" (Gilbert, 2003). Therefore we need a competence-oriented approach to the function of morphogens in morphogenesis. This proposal arises from a comparison of the action of morphogens in different contexts. It is known that the same morphogen can act at different stages of development, in different organisms and during normal and pathological processes in adult organisms. For example Wnt/ $\beta$-catenin pathway at blastula stage is crucial for the formation of dorso-ventral pattern and is expressed dorsally (de Robertis and Kuroda 2004). During gatsrulation the same pathway is involved in the process of posteriorisation of the neural tube (Kiecker and Niehrs 2001). This pathway plays different roles during subsequent stages and also for the maintenance of adult morphology (see below). The same is true for BMP (e.g Wawersik et al., 2005) and other substances. Analysis of the action of some well known diffusible morphogens and intracellular factors shows that some morphogens work in similar ways in many different contexts while others do not. li may be interesting in this respect to study the signaling pathway in cancerogenesis and teratological abnormalities.

Endogenous substances which play a role in carcinogenesis are commonly divided into two or more groups. The products of certain genes (oncogenes) and some other substances tend to enhance malignant growth while other substances (e.g. products of tumor suppressor genes) tend rather to inhibit. This occurs via the enhancement or inhibition of proliferation, differentiation and apoptosis. The same events play a key role in morphogenesis. Thus it seems that the morphogenetically active substances could be divided in a similar manner. In what follows I will briefly attempt to describe the function of selected morphogens in the context of cell behaviour, by means of their role in carcinogenesis. This attempt is a kind of proposal to focus investigations on cell behaviour rather than to answer the question about the function of morphogens in development.

First of all we should consider the role of selected substances in proliferation, cell movement, differentiation and apoptosis. Also the influence of morphogens on developmental fields by using teratological abnormalities should be studied. Since our goal is knowledge about the ultimate consequence of morphogen activity on the cell behaviour, we should be selective and use only relatively well studied processes.

\section{Shh}

Sonic hedgehog (Shh) is secreted protein from hedgehog family. Is it possible to consider the influence that Shh may have upon cell behaviour? It appears that Shh acts as a rule in the context of physiological or abnormal growth. The Shh pathway is aberrantly activated in several human malignancies including basal cell carcinoma (Holikova et al., 2004), medulloblastoma (Leung etal., 2004), prostate (Sheng etal., 2004) and gut cancers (Oniscu et al., 2004). Shh is important for limb bud outgrowth (Kraus et al., 2001) and growth of the trachea (Kato et al., 2004). Sonic hedgehog has a mitogenic effect onto stem cells of the subventricular zone (SVZ) in the mouse forebrain (Palma et al., 2005). Shh was shown to pattern cerebellum by maintenance of proliferation and is required to generate a sufficient number of precursor cell pools (Coralles et al., 2004). The expression of Shh in human adult gut epithelium is strongest in basal layers suggesting the role of the Shh pathway in the maintenance of its stem cell population (Nielsen et al., 2004). Deficiency of Shh leads to different expressions of holoprosencephaly due to lack or deficiency of separation of the cerebral hemispheres (Ahlgren et al., 1999). This effect clearly demonstrates the global role of this morphogen since Shh absence causes disorder in the developmental field. Shh was shown to be required for survival of myogenic and chondrogenic somitic lineages (Teillet etal., 1998). All of the above reported processes are directly related to growth and proliferation. On the other hand, the substance has some functions unrelated to proliferation such as left-right axis formation (King and Brown, 1999). Moreover Shh seems some cases to be in involved in cell differentiation, for example during chondrogenesis (Iwamoto et al., 1999). It was suggested, however, that the role of Shh may be generation of precursor cells competent to chondrogenesis in response to BMP signalling (Murtaugh et al., 1999).

\section{Wnt/ß-catenin pathway}

The next focus of our attention will be Wnt and the Wnt mediated signalling pathway. The $\mathrm{Wnt} / \beta$-catenin pathway is acti- 
vated in growing and extending tissues (Megason and McMahon, 2002) and cancer cells (Moon et al., 2004). Activation of the Wnt pathway helps to maintain the stem-cell character of epidermis (Alonso and Fuchs, 2003) and haematopoietic cells (Reya et al., 2003) and inhibit differentiation of preadipocyte to adipocytes (Ross et al., 2000). It seems that the $\mathrm{Wnt} / \beta$-catenin pathway is crucial for maintaining embryonic stem cells in their undifferentiated state (see also Feng et al., 2004). On the other hand it was shown that the Wnt pathway acts in a stage dependent manner and promotes both neuronal cell differentiation (Hirabayashi et al., 2004) and self-renewal of neural precursor cells (Megason and McMahon, 2002, Kubo et al., 2003). Different components of the Wnt signalling pathway are involved in human tumors or experimental cancer models (Morin, 1999, Moon et al., 2004, Logan and Nusse, 2004). Mutational activation of human $\beta$ catenin was found in human colon cancer, hepatocellular carcinoma, ovarian cancer, melanomas, prostate cancer and others. The inactivation of Wnt3 leads to tetra-amelia (loss of all four limbs: Niemann et al., 2004). Interestingly, the abnormal activation of the Wnt pathway alters the developmental potential of embryonic lung endoderm and leads to highly proliferative intestinal like tissue (Okubo and Hogan, 2004). Inactivation of pathway due to elevated beta-catenin degradation enhances neuronal apoptosis and is associated with Alzheimer's disease (Zhang et al., 1998). Therefore, the Wnt pathway often plays a role of activator of proliferation.

\section{Retinoic acid (RA)}

RA affects cancerogenesis in the opposite way to Wnt, that is, inhibits it. It leads to the arrest of cell proliferation, apoptosis and differentiation and is used as a differentiation-inducing agent in malignant diseases (Jimenez-Lara et al., 2004). RA is involved in the expansion of posterior hindbrain structures (Dupe and Lumsden, 2001) and is required for neuronal differentiation acting in opposition to FGF mediated proliferation (Corral and Storey, 2004). RA is required for control of cell proliferation during vasculogenesis because its deficiency leads to uncontrolled proliferation (Lai et al., 2003). RA was shown to decrease the proliferative activity of migrating neural crest cells (Salvarezza and Rovasio, 1997). Application of RA leads to different global anomalies like limb and lower body duplication (Niederreiter et al., 1996) or loss of the posterior part of an embryo (Kessel, 1992). Interestingly, RA mimics Shh deficiency leading to holoprosencephaly (Cordero et al., 2002). This effect is compatible with the antiproliferative character of RA activity. RA is required for the establishment of limb anterior-posterior polarity by the generation of ZPA (Niederreither et al., 2002) and also is involved in limb (Maden, 1998) and lens (Henry, 2003) regeneration. Recently it was shown that RA can induce postnatal alveolar regeneration (Maden and Hind, 2004), an effect successfully used for experimental treatment of lung emphysema in mouse.

\section{BMP/DPP}

Bone morphogenetic protein (and closely related DPP) seems to be involved in the inhibition of proliferation and cell movement. The substance acts as growth inhibitor in different tumours (e.g Kawamura et al., 2002, Miyazaki et al., 2004). BMP is expressed in the ventral part of Xenopus embryos, but is inhibited in the dorsal part which undergoes convergent extension (Dale and Jones, 1999). BMP leads to apoptosis in the interdigital mesenchyme (Merino et al., 1998), inhibits intestinal stem cell selfrenewal (He et al., 2004), growth in trachea of Drosophila (Kato et al., 2004), induces neurogenesis in neural crest cells (Shah et al., 1996), stimulates embryonic rat stem cells to develop into neural crest (Cajavelli et al., 2004) and specifies dorsal cell types in neural tube (Chesnutt et al., 2004). On the other hand, BMP is probably positively involved in proliferation of chondrocytes in the growth plate (Minina et al., 2001).

\section{Cell reactions to morphogens are context-dependent}

Experimental approaches to the effects of morphogens upon cell behaviour can provide interesting insights to morphogenesis. However, no one-to-one relation between the morphogen and its function can be postulated: BMP acts in most cases as a suppressor of proliferation but sometimes as an activator. Similarly, the classical oncogene Ras leads both to enhancement of proliferation and inhibition (Diaz et al., 2002). It seems that although a substance can have some "canonical" functions, the opposite ones also take place. The situation is complicated by a positive and negative feedback regulation of different morphogens and crosstalks between different signalling pathways. For example, the TGF- $\beta /$ Smad pathway inhibits the proliferation of epithelial and other cell types, either by blocking cell-cycle progression in G1 or by stimulating apoptosis (Ten Dijke et al., 2002). Additionally, TGF- $\beta$ is involved in differentiation by stimulating the conversion of fibroblasts into myofibroblasts in the course of wound healing and promotes the formation of collagen-rich scar tissue. Loss of growth inhibition through TGF- $\beta$-mediated pathways contributes to the genesis of several types of human cancers. On the other hand, malignant transformed cells are often resistant to growth inhibitory action of TGF- $\beta$. Moreover the TGF- $\beta$ signal itself has recently been shown to support cancer cells, especially in the late phase of tumor progression (Bachman and Park, 2005). This could be caused by cooperative effect of TGF and Ras which alters the TGF- $\beta$ response of epithelial cells (Massagué and Chen, 2000). It was shown that cooperation between the Ras oncogene and TGF signalling leads to the transdifferentiation of mammary epithelial cells into a highly invasive and metastatic phenotype (Oft et al., 1998). TGF and Ras pathways interact in pancreatic malignant cells leading to epithelial-mesenchymal transformation and result in an invasive phenotype (Ellenrieder et al., 2001). Wnt/ $\beta$-catenin and TGF/Smad pathways interact during early Xenopus development and are able enhance each other (de Robertis and Kuroda, 2004).

\section{Concluding remarks}

From a theoretical point of view any local explanation of morphogenesis is not appropriate. It seems rather that both local and global interactions are important parts of the development. This means that the action of any morphogen should be considered in the context of the morphogenetic behaviour of cells and tissues. Interactions between mechanical and chemical influences should be rigorously studied. It seems that the main action of morphogens consists in the modulation of cell behaviour in a 
context and competence-dependent manner. This can occur either directly or by complicated processes involving many pathways. However, it is not clear whether all the experimental findings could be interpreted in this way: the experimental data already cited, provided by Asashima and his co-workers (2000) suggest direct differentiating action of different concentrations of morphogen, although indirect influence via cell behaviour could not be ruled out. Another example is the role of Shh gradient in the ventral patterning of the neural tube which cannot be easily interpreted as a stimulation of proliferation. Shh is secreted by floor plate cells and forms a long-range gradient important for dorso-ventral patterning of neural tube (Briscoe and Ericson 2001). Whether the patterning of the neural tube is directly caused or simply mediated by a graded activity of Shh is not clear since an Shh-independent mechanism has also been observed (Persson et al., 2002). Further experiments are needed in order to define a specific role of morphogens in morphogenesis and differentiation.

It could be argued that the approach proposed in this paper ignores the specificity of the molecular action of morphogenes. This objection disappears, however, if we remember that the same morphogens and pathways play different roles in different species and even at different sites or at different stages of development of the same species. As mentioned above, the "famous" Wnt/ $\beta$-catenin pathway acts in most known phyla, at different developmental stages and in the adult organisms. This means that the morphogens are most probably playing a permissive role within a given context. In order to overcome this difficulty, interactions between different pathways should be postulated. This postulation, however, leads to an increase in explanatory complexity. Meanwhile, the higher is the level of molecular complexity, the lower would be the possibility of explaining the robustness of morphogenesis. Therefore a kind of a complementarity emerges between global robust processes and local, precise mechanisms. Embryonic regulations have shown that the cell's fate depends upon something more than just highly specific local interactions. Rather, the cell's fate is a function both of the molecular microenvironment and of global conditions. Both factors influence the behaviour of a particular cell within the framework of its history and actual conditions. The latter, which are also embraced by the notion of a competence, undoubtedly plays a causal role by restricting the instructive role of external influences. Therefore development can be considered as a stepwise interaction between embryonic material and external influences.

Whatever may be the proper function of morphogens, they (regarded as a system) are only one, although a necessary, part of the developmental program. The mechanical processes and the dynamics itself perform the functions of both context and causes.

Crucial in this connection is the concept of morphogenetic field that can be helpful by defining the boundary conditions which determine development. A morphogenetic or a developmental field is a discrete area of the embryo and a mediator between phenotype and genotype (Gilbert et al., 1996). The morphogenetic field can be also defined as a piece of embryonic material constituting a given morphological structure (Davidson, 1993). Clinical geneticists interpret malformation in terms of developmental field defects (Martinez-Frias et al., 1998). But although the notion of morphogenetic field is frequently used in developmental biology and medical genetics, little is known about its nature. Gordon (1999) suggests that the morphogenetic field is the trajectory of a differentiation wave. Further progress in both developmental biology and theory of science is required in order to make this concept more transparent.

It can be proposed that both the ligand-mediated and stressmediated changes in the development of the organism play a causal role in the sense of a causa efficiens. Gradients of morphogens, metabolic gradients, mechanical stresses and competence create the boundary conditions, or causa formalis and influence the factors which are acting as efficient causes via the modification of cell behaviour within embryonic areas described as morphogenetic fields.

\section{Acknowledgments}

Isincerely thank Lev Beloussov, Richard Gordon, Katherine Munn and Johannes Wirz for their interest in this work, long fruitful discussions, references and linguistic help. My thanks go also to Barry Smith, Berenike Flott-Rahmel and Tatjana Welikanowa.

\section{References}

AHLGREN, S.C. and BRONNER-FRASER, M. (1999). Inhibition of sonic hedgehog signaling in vivo results in craniofacial neural crest cell death. Curr. Biol. 9: 130414.

ALONSO, L. and FUCHS, E. (2003). Stem cells in the skin: waste not, Wnt not. Genes Dev. 17: $1189-1200$

ANDERSON, P.W. and STEIN, D.L. (1987). Broken Symmetry, Emergent Properties, Dissipative structures, Life: Are They Related?» In: (Ed. YATES, F.E.), Self-Organizing Systems: The Emergence of Order, Plenum Press, New York: 445-457.

ARISTOTLE, Metaphysics, in: The Complete Works of Aristotle, ed. by Jonathan Barnes. Princeton, 1984.

ARISTOTLE, Posterior analytics, translated by Mure G.R.G. MIT Classics: http:// classics.mit.edu/Aristotle/metaphysics.html

ASASHIMA, M., ARIIZUMI, T. and MALACINSKI, G.M. (2000). In vitro control of organogenesis and body patterning by activin during early amphibian development. Comp. Biochem. Physiol. B Biochem. Mol. Biol.126:169-78.

BACHMAN, K.E. and PARK, B.H. (2005). Duel nature of TGF-beta signaling: tumor suppressor vs. tumor promoter Curr. Opin. Oncol. 17:49-54.

BARNES, J. (1982). Aristotle. Oxford. Oxford University Press.

BELENKAYA, T.Y., HAN, C., YAN, D., OPOKA, R.J., KHODOUN, M., LIU, H. and LIN, X. (2004). Drosophila Dpp morphogen movement is independent of dynamin-mediated endocytosis but regulated by the glypican members of heparan sulfate proteoglycans. Ce//119:231-44.

BELOUSSOV, L.V. (1998). The Dynamic architecture of developing organism. Dordrecht, Kluwer Academic Publishers.

BELOUSSOV, L.V. and ERMAKOV, A.S. (2001). Artificially applied tensions normalize development of relaxed Xenopus Laevisembryos Rus. J. Dev. Biol.: 32:288-94.

BELOUSSOV, L.V. and SNETKOVA, E.V. (1994). The dependence of the differentiation potentials of fragments of the marginal zone in early gastrulas of the clawed toad on their morphogenetic movements. Ontogenez 25:63-71. Russian.

BERTOCCHINI, F., SKROMNE, I., WOLPERT, L. and STERN, C.D. (2004). Determination of embryonic polarity in a regulative system: evidence for endogenous inhibitors acting sequentially during primitive streak formation in the chick embryo. Development 31:3381-90.

BOVERI, T. (1901). Über die Polarität des Seeigeleiers. Eisverh. Phys. Med. Ges. Würzburg 34:145-175.

BRISCOE, J. and ERICSON, J. (2001). Specification of neuronal fates in the ventral neural tube. Curr. Opin. Neurobiol. 11: 43-49.

CHERDANTSEV, V.G. (2003) Morfogenez i evolyutsiya (Morphogenesis and 


\section{Evolution), Moscow: KMK.}

CHERDANTSEV, V.G. and KRAUSS, YU.A. (1996). Gastrulation in the marine hydroid Dynamena pumila: an example of evolutionary anticipation based on developmental self-organization. Evolutionary Theory. 11: 89-98.

CHESNUTT, C., BURRUS, L.W., BROWN, A.M. and NISWANDER, L. (2004) Coordinate regulation of neural tube patterning and proliferation by TGFbeta and WNT activity. Dev. Biol. 274:334-47.

CHILD, C. M. (1941) Patterns and Problems of Development. University of Chicago Press, Chicago.

CORRALES, J.D., ROCCO, G.L., BLAESS, S., GUO, Q. and JOYNER, A.L. (2004). Spatial pattern of sonic hedgehog signaling through Gli genes during cerebellum development. Development 131:5581-90.

CORDERO, D., MARCUCIO, R., HU, D., GAFFIELD, W., TAPADIA, M. and HELMS, J.A. (2002). Temporal perturbations in sonic hedgehog signaling elicit the spectrum of holoprosencephaly phenotypes. Am. J. Med.Genet. 109:1-15.

DALE, L. and JONES, C.M. (1999). BMP signalling in early Xenopus development. Bioessays 21:751-60.

DAY, S.J. and LAWRENCE, P.A. (2000). Measuring dimensions: the regulation of size and shape. Development 127:2977-87.

DAVIDSON, E.H. 1993 Later embryogenesis: regulatory circuitry in morphogenetic fields. Development 118:665-90.

DEL CORRAL, R.D. and STOREY, K.G. (2004). Opposing FGF and retinoid pathways: a signalling switch that controls differentiation and patterning onset in the extending vertebrate body axis. Bioessays 26:857-69.

DE ROBERTIS, E.M., LARRAIN, J., OELGESCHLAGER, M. and WESSELY, O. (2000). The establishment of Spemann's organizer and patterning of the vertebrate embryo. Nature Rev. Gen. 1:171-81.

DE ROBERTIS, E.M. and KURODA, H. (2004). Dorsal-ventral patterning and neural induction in Xenopus embryos. Annu. Rev. Cell Dev. Biol. 20:285-308.

DIAZ, R. AHN, D., LOPEZ-BARCONS, L., MALUMBRES, M., PEREZ DE CASTRO, I., LUE, J., FERRER-MIRALLES, N., MANGUES, R., TSONG, J., GARCIA, R. PEREZ-SOLER, R. and PELLICER, A. (2002). The $N$-ras proto-oncogene can suppress the malignant phenotype in the presence or absence of its oncogene. Cancer Res. 62:4514-4518.

DRIEVER, W. and NUSSLEIN-VOLHARD, C. (1988). A gradient of bicoid protein in Drosophila embryos. Cel/4:83-93.

DUBRULLE, J. and POURQUIÉ, O. (2004). fgf8 mRNA decay establishes a gradient that couples axial elongation to patterning in the vertebrate embryo. Nature 427:419-422.

DUPE, V. and LUMSDEN, A. (2001). Hindbrain patterning involves graded responses to retinoic acid signalling. Development 128:2199-208.

EPHRUSSI, A. and ST JOHNSTON, D. (2004). Seeing is believing: the bicoid morphogen gradient matures. Cel/116:143-52.

ELLENRIEDER, V., HENDLER, S.F., BOECK, W., SEUFFERLEIN, T., MENKE, A. RUHLAND, C., ADLER, G. and GRESS, T.M. (2001). Transforming growth factor beta1 treatment leads to an epithelial-mesenchymal transdifferentiation of pancreatic cancer cells requiring extracellular signal-regulated kinase 2 activation. Cancer Res. 61:4222-8.

FARGE, E. (2003). Mechanical induction of Twist in the Drosophila foregut/ stomodeal primordium. Curr. Biol. 13:1365-77.

FENG, Z., SRIVASTAVA, A.S., MISHRA, R. and CARRIER, E. (2004). A regulatory role of Wnt signaling pathway in the hematopoietic differentiation of murine embryonic stem cells. Biochem. Biophys. Res. Commun. 324:1333-9.

FRANKHAUSER, G. (1945). The effects of changes in chromosome number on amphibian development. Quart. Rev. Biol. 20: 20-78.

GAJAVELLI, S., WOOD, P.M., PENNICA, D., WHITTEMORE, S.R. and TSOULFAS, $P$. (2004). BMP signaling initiates a neural crest differentiation program in embryonic rat CNS stem cells. Exp Neurol. 188:205-23.

GARCIA-CARDENA, G., COMANDER, J. andESRON, K.R., BLACKMAN, B.R. and GIMBRONE, M.A. JR. (2001). Biomechanical activation of vascular endothelium as a determinant of ist functional phenotype PNAS 98: 4478-4485.

GILBERT, S.F. (2003) Developmental Biology. Sinauer. Sunderland, Mass.

GILBERT, S.F., OPITZ, J.M. and RAFF, R.A.(1996). Resynthesizing Evolutionary and Developmental Biology. Dev. Biol. 173: 357-372.
GILBERT, S. F. and SARKAR, S. (2000). Embracing complexity: Organicism for the Twenty-first Century. Dev. Dynamics 219:1-9.

GORDON, R. (1999). The Hierarchical Genome and Differentiation Waves: Novel Unification of Development, Genetics and Evolution. Singapore \& London: World Scientific \& Imperial College Press.

GURDON, J. B. and BOURILLOT, P.-Y. (2001). Morphogen gradient interpretation. Nature 413:797-803.

HARRIS, A.K. (1987). Cell motility and the problem of anatomical homeostasis. J. Cell. Sci. supp. 8:121-140.

HE, X.C., ZHANG, J. and TONG, W.G. (2004). BMP signaling inhibits intestinal stem cell self-renewal through suppression of Wnt-beta-catenin signaling. Nat. Genet. 36:1117-21

HENRY, J.J. (2003). The cellular and molecular bases of vertebrate lens regeneration. Int. Rev. Cytol. 228:195-265.

HIRABAYASHI, Y., ITOH, Y., TABATA, H., NAKAJIMA, K., AKIYAMA, T., MASUYAMA, N. and GOTOHY. (2004). The Wnt/beta-catenin pathway directs neuronal differentiation of cortical neural precursor cells. Development 131:27912801.

HOLIKOVA, Z., MASSI, D., LOTTI, T. and HERCOGOVA, J. (2004). Insight into the pathogenesis of sporadic basal cell carcinoma. Int. J. Dermatol. 43:865-9.

HÖRSTADIUS, S. (1939). The mechanics of the sea urchin development studied by operative methods. Bio. Rev. 14:132-179.

HORNBERGER, T.A., ARMSTRONG, D.D., KOH, T.J., BURKHOLDER, T.J. and ESSER K.A. (2005). Intracellular signalling specificity in response to uniaxial vs. multiaxial stretch: implications for mechanotransduction. Am. J. Physiol. Cell. Physiol. 288:185-94.

HOUCHMANDZADEH, B., WIESCHAUS, E. and LEIBLER, S. (2002). Establishment of developmental precision and proportions in the early Drosophila embryo. Nature 415:798-802.

HOVE, J.R., KOSTER, R.W., FOROUHAR, A.S. ACEVEDO-BOLTON, G., FRASER, S.E.and GHARIB, M. (2003). Intracardiac fluid forces are an essential epigenetic factor for embryonic cardiogenesis. Nature. 421:172-7.

HUANG, S. and INGBER, D.E. (2000). Shape-Dependent Control of Cell Growth Differentiation and Apoptosis: Switching between Attractors in Cell Regulatory Networks. Exp. Cell Res. 261:91-103.

INGBER, D.E. (2003). Mechanobiology and diseases of mechanotransduction Ann. Med. 35:564-77.

IWAMOTO, M., ENOMOTO-IWAMOTO, M. and KURISU, K. (1999). Actions of hedgehog proteins on skeletal cells. Crit. Rev. Oral Biol. Med.10:477-86.

JAEGER, J., SURKOVA, S., BLAGOV, M., JANSSENS, H., KOSMAN, D., KOZLOV, K.N., MANU, MYASNIKOVA, E., VANARIO-ALONSO, C.E., SAMSONOVA, M., SHARP, D.H. and REINITZ, J. (2004). Dynamic control of positional information in the early Drosophila embryo. Nature 430(6997):368-71.

JIMENEZ-LARA A.M., CLARKE N., ALTUCCI L. and GRONEMEYER H. (2004). Retinoic-acid-induced apoptosis in leukemia cells. Trends Mol. Med. 10:508 15.

KATO, K., CHIHARA, T. and HAYASHI, S. (2004). Hedgehog and Decapentaplegic instruct polarized growth of cell extensions in the Drosophilatrachea. Development 131:5253-5261.

KAWAMURA, C., KIZAKI, M. and IKEDA, Y. (2002). Bone morphogenetic protein (BMP)-2 induces apoptosis in human myeloma cells. Leuk. Lymphoma 43:635-

KESSEL, M. (1992). Respecification of vertebral identities by retinoic acid. Deve/opment 115:87-501.

KING, T. and BROWN N.A. (1999). Developmental biology: Antagonists on the left flank. Nature 401: 222-223.

KIRSCHNER, M., GERHART, J. and MITCHISON, T. (2000). Molecular Vitalism: Cel/100:79-88.

KNECHT, A.K. and HARLAND, R.M. (1997). Mechanisms of dorsal-ventral patterning in noggin-induced neural tissue. Development 124:2477-88.

KUBO, F., TAKEICHI, M. and NAKAGAWA, S. (2003). Wnt2b controls retinal cell differentiation at the ciliary marginal zone. Development 130: 587-598.

LAI, L., BOHNSACK, B.L., NIEDERREITHER, K. and HIRSCHI, K.K. (2003) Retinoic acid regulates endothelial cell proliferation during vasculogenesis. 


\section{Development 130:6465-74.}

LAWRENCE, P.A. (2001). Wingless signalling: more about the Wingless morphogen. Curr. Biol. 11:R638-9.

LEUNG, C., LINGBEEK, M, SHAKHOVA, O, LIU, J., TANGER, E., SAREMASLANI, P., VAN LOHUIZEN, M. and MARINO, S. (2004). Bmi1 is essential for cerebellar development and is overexpressed in human medulloblastomas. Nature428:33741.

LOGAN, C.Y. and NUSSE, R. (2004). The Wnt signaling pathway in development and disease. Annu. Rev. Cell. Dev. Biol. 20:781-810.

MADEN, M. 1998. Retinoids as endogenous components of the regenerating limb and tail. Wound Repair Regen. 6(4):358-65.

MADEN, M. and HIND, M. (2004). Retinoic acid in alveolar development, maintenance and regeneration. Philos. Trans. R. Soc. Lond. B Biol. Sci. 359:799-808.

MAHNER, M. and BUNGE, M. (1997). Foundations of biophilosophy. Springer. Berlin.

MARTINEZ-FRIAS, M.L., FRIAS J.L. and OPITZ, J.M. (1998). Errors of morphogenesis and developmental field theory. Am. J. Med. Genet. 76:291-6.

MASSAGUÉ, J. and CHEN, Y.G. (2000). Controlling TGF-beta signaling. Genes Dev. 14:627-44.

MEGASON, S. G. and MCMAHON, A. P. (2000). A mitogen gradient of dorsal midline Wnts organizes growth in the CNS. Development 129:2087-2098

MERINO, R., GANAN, Y., MACIAS, D., ECONOMIDES, A.N., SAMPATH, K.T. and HURLE, J.M. (1998). Morphogenesis of digits in the avian limb is controlled by FGFs, TGFbetas and noggin through BMP signaling. Dev. Biol. 200:35-45.

MIYAZAKI, H., WATABE, T., KITAMURA, T. and MIYAZONO, K. (2004). BMP signals inhibit proliferation and in vivo tumor growth of androgen-insensitive prostate carcinoma cells. Oncogene 23:9326-35

MININA, E., WENZEL, H.M., KRESCHEL, C. KARP, S., GAFFIELD, W., MCMAHON, A.P. and VORTKAMP, A. (2001). BMP and Ihh/PTHrP signaling interact to coordinate chondrocyte proliferation and differentiation. Development128:452334.

MORIN, P.J. (1999). beta-catenin signaling and cancer. Bioessays 21:1021-30.

MOON, R.T., KOHN, A.D., DE FERRARI, G.V. and KAYKAS, A. (2004). WNT and beta-catenin signalling: diseases and therapies. Nat. Rev. Genet. 5:691-701.

MURTAUGH, L.C., CHYUNG, J.H. and LASSAR, A.B. (1999). Sonic hedgehog promotes somitic chondrogenesis by altering the cellular response to BMP signaling. Genes Dev. 13:225-37.

NAMBA, R., PAZDERA, T.M., CERRONE, R.L. and MINDEN, J.S. (1997). Drosophila embryonic pattern repair: how embryos respond to bicoid dosage alteration. Development 124:1393-403.

NEWMAN, S.A. and MÜLLER, G.B. (2001). Epigenetic mechanisms of character origination. In: (Ed. Wagner. G.P.) The Character Concept in evolutionary Biology Academic Press, San Diego. pp. 559—579.

NIEDERREITHER, K., WARD, S.J., DOLLE, P. and CHAMBON, P. (1996). Morphological and molecular characterization of retinoic acid-induced limb duplications in mice. Dev. Biol. 176:185-98.

NIEDERREITHER, K., VERMOT J., SCHUHBAUR, B., CHAMBON, P. and DOLLÉ, $P$. (2002). Embryonic retinoic acid synthesis is required for forelimb growth and anteroposterior patterning in the mouse Development 129:3563-3574.

NIELSEN, C.M., WILLIAMS, J., VAN DEN BRINK, G.R., LAUWERS, G.Y. and ROBERTS, D.J. (2004). Hh pathway expression in human gut tissues and in inflammatory gut diseases. Lab. Invest. 84:1631-42.

NIEMANN, S., ZHAO, C., PASCU, F., STAHL, U., AULEPP, U., NISWANDER, L., WEBER, J.L. and MULLER, U. (2004). Homozygous WNT3 mutation causes tetra-amelia in a large consanguineous family. Am. J. Hum. Genet. 74:558-563.

OFT, M., HEIDER, K.H. and BEUG, H. (1998). TGF-beta signaling is necessary for carcinoma cell invasiveness and metastasis. Curr. Biol. 8:1243-52.
OKUBO, T. and HOGAN, B. L. (2004). Hyperactive Wnt signaling changes the developmental potential of embryonic lung endoderm. J. Biol. 3:11.

ONISCU, A., JAMES, R.M., MORRIS, R.G., BADER, S., MALCOMSON, R.D. and HARRISON, D.J. (2004). Expression of Sonic hedgehog pathway genes is altered in colonic neoplasia. J. Pathology 203:909-17.

OPAS, M. (1994) Substratum mechanics and cell differentiation. Int. Rev. Cytol. 150:119-37.

PALMA, V., LIM, D.A. and DAHMANE, N. (2005). Sonic hedgehog controls stem cell behavior in the postnatal and adult brain. Development 132:335-44.

PERSSON, M., STAMATAKI, D., TE WELSCHER, P. andERSSON, E., BOSE, J., RUTHER, U., ERICSON, J. and BRISCOE, J. (2002). Dorsal-ventral patterning of the spinal cord requires Gli3 transcriptional repressor activity. Genes Dev. 16:2865-78.

POLANYI, M. (1968). Life's Irreducible Structure, Science 160:1308-12.

POWER, M.A. and TAM, P.P. (1993). Onset of gastrulation, morphogenesis and somitogenesis in mouse embryos displaying compensatory growth. Anat. Embryol. (Berl) 187:493-504.

RANDS, G.F. (1986). Size regulation in the mouse embryo. II. The development of half embryos. J. Embryol. Exp. Morphol. 98:209-17.

REYA, T., DUNCAN, A.W., AILLES, L., DOMEN, J., SCHERER, D. C., WILLERT, K., HINTZ, L., NUSSE, R. and WEISSMAN, I. L. (2003). A role for Wnt signalling in self-renewal of haematopoietic stem cells. Nature 423:409-414.

ROSS, S.E., HEMATI, N., LONGO, K.A., BENNETT, C.N., LUCAS, P.C., ERICKSON, R.L. and MACDOUGALD, O.A. (2000). Inhibition of adipogenesis by Wnt signaling. Science 289:950-953.

SALVAREZZA, S.B. and ROVASIO, R.A. (1997). Exogenous retinoic acid decreases in vivo and in vitro proliferative activity during the early migratory stage of neural crest cells. Cell Prolif. 30:71-80.

SHAH, N.M., GROVES, A.K. andERSON, D.J. (1996). Alternative neural crest cell fates are instructively promoted by TGFbeta superfamily members. Ce//85:33143.

SMITH, J.C. and GURDON J.B. (2004). Many ways to make a gradient. Bioessays 26:705-6.

SPITZER, A. (1923). Uber den Bauplan des normalen und missgebildeten Herzen. Versuch einer phylogenetischen Theorie. Virchows Arch. (A) 243:81-272

TEILLET, M.-A., Y. WATANABE, P. JEFFS, D. DUPREZ, F. LAPOINTE and DOUARIN, N.M.L. (1998). Sonic hedgehog is required for survival of both myogenic and chondrogenic somitic lineages. Development 125: 2019-2030.

TSIKOLIA, N. (2003). What is the role of morphogen gradients in development? Riv. Biol. 96: 293-315.

WAGNER, G. (1994). Homology and mechanisms of development. In (Ed. Hall, B.K.) Homology. The hierarchical basis of comparative biology. Academic press. San Diego.

WAWERSIK, S., EVOLA, C. and WHITMAN, M. (2005). Conditional BMP inhibition in Xenopus reveals stage-specific roles for BMPs in neural and neural crest induction. Dev. Biol. 277: 425-42.

WOLPERT, L. (1996). One hundred years of positional information. Trends Genet. 12:359-64.

ZENG, X., GOETZ, J.A., SUBER, L.M., SCOTT, W.J, Jr., SCHREINER, C.M. and ROBBINS, D.J. (2001). A freely diffusible form of Sonic hedgehog mediates long-range signalling. Nature 411:716-20.

ZHANG, Z., HARTMANN, H., DO, V.M. ABRAMOWSKID, STURCHLER-PIERRAT C, STAUFENBIEL M, SOMMER B, VAN DE WETERING M, CLEVERS, H., SAFTIG, P., DE STROOPER, B., HE, X. and YANKNER, B.A. (1998). Destabilization of beta-catenin by mutations in presenilin-1 potentiates neuronal apoptosis. Nature 395:698-702. 